\title{
Indhold 2015
}

\section{Artikler}

Balvig, Flemming: Kriminalitet og retsbevidsthed - i Grønland .................. 7

Laine, Matti: Ryssland och Finlands kriminalpolitik ..................................... $\quad 79$

Gröning, Linda: Tilregnelighet og utilregnelighet: begreper og regler ........ 112

Träskmann. Per Ole: Brottslighet och brottskontroll i Finland och de andra

Nordiska länderna: Banbrytare eller eftersläntrare?

Johnsen, Berit og Hans Jørgen Engbo: Forvaring i Norge, Danmark og

Grønland - noen likheter og ulikheter

Hansen, Gunnar Vold: Positiv kriminologi bør gi nye krav til programvirksomhet

Johansen, Louise Victoria og Annette Esdorf: Personundersøgelser mellem forskning og praksis - samarbejdets muligheder

Kimpimäki, Minna: Humanitär verksamhet eller organiserad brottslighet? Ordnande av olaglig inresa

i Finland

Lahti, Raimo: Straffrätten på 2020-talet - från Cesare Beccarias Om britt och straff (1764) till en allt mer internationell och europeisk straffrätt 262

Olaussen, Leif Petter: Prisonisering - en ubekreftet »jernlov« om sosialt liv bak murene 276

\section{Boganmeldelser}

Garde, Peter af Per Ole Träskman: August Goll - en shakespearesk kriminalist og hans tid

Hammerlin, Yngve og Paul Leer-Salvesen af Ida Koch: Voldens ansikteren dialog om ondskab, ansvar og håb

Christensen, Mikkel Jarle af Helene O.I. Gundhus: Fra det evige politi til prosjektpolitiet. En kamp om position og ideologi

Olesen, Annette af Lena Roxell: Løsladt og gældsat

Garde, Peter af Vagn Greve: Danmarks justitsministre 1813-2013

Helenius, Dan af Per Ole Träskman: Straffrättslig jurisdiktion

Hobbs, Dick af Paul Larsson: Lush Life. Constructing Organized Crime in the UK 
Rui, Jon Petter af Helén Örnemark Hansen: Hvitvaskning: Fenomenet, regelverket, nye strategier

$\varnothing y$, Nils E. af Morten Holmboe: Kommentarbok til offentleglova

\section{Debat}

Johansen, Nicolay B.: Kriminologers bruk af teori: Svar til Leif Petter Olaussen

\section{Diverse}

Indhold 2014

Årsberetning

Tham, Henrik: Hanns Von Hofer 1944-2014

Elholm, Thomas og Per Ole Träskman: Vagn Greve 1938-2014

Ericsson, Kjersti: Til minne om Nils Christie 